TERESA CHIRKOWSKA-SMOLAK

\author{
$\stackrel{\circ}{\|}$

\section{DORASTANIE DO LOJALNOŚCI. LOJALNOŚĆ WOBEC ORGANIZACJI PRACOWNIKÓW POKOLENIA Y}

\begin{abstract}
Teresa Chirkowska-Smolak, Dorastanie do lojalności. Lojalność wobec organizacji pracowników pokolenia $Y$ [Growing up to loyalty. Organizational loyalty of Generation Y employees]

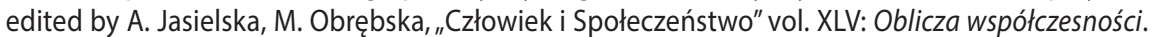
Perspektywa psychologiczna [Faces of modernity. A psychological perspective], Poznań 2018, pp. 151-167, Adam Mickiewicz University. Faculty of Social Sciences Press. ISSN 0239-3271.
\end{abstract}

The aim of the work is to present the problem of organizational loyalty among representatives of the $\mathrm{Y}$ generation, stereotypically perceived as selfish, arrogant and disloyal. Based on the results of three studies ( $\mathrm{N} 1=336, \mathrm{~N} 2=213$ and $\mathrm{N} 3=118$ ), the level of organizational loyalty in three age groups was compared (younger and older representatives of Generation $Y$ and employees from generation $\mathrm{X}$ ). There was also analyzed the relationship between loyalty and job satisfaction, and between loyalty, and organizational justice. The obtained results allow to state that loyalty is moderately related to organizational factors (satisfaction, perceived justice) and that a similar pattern of dependence occurs in all distinguished age categories. The results show that loyalty grows with age, and employees by the age of 30 have significantly lower level of loyalty to the organization compared to employees from their parents' generation.

Teresa Chirkowska-Smolak, Instytut Psychologii UAM, ul. Szamarzewskiego 89, 60-568 Poznań, e-mail: teresa.chirkowska-smolak@amu.edu.pl 


\section{Wprowadzenie}

Celem niniejszego artykułu jest analiza lojalności wobec organizacji u przedstawicieli pokolenia Y. Jest to pokolenie, które wchodzi na rynek pracy lub jest już na nim obecne. Są to osoby urodzone w Polsce w latach 1980-2000, które były wychowane w nowej rzeczywistości polityczno-gospodarczej. Inne nazwy tego pokolenia to pokolenie cyfrowe czy milenialsi (osiągnęli dorosłość u progu nowego tysiąclecia, aczkolwiek obejmuje to starszych Igreków). Postawy pracowników tego pokolenia stanowią przedmiot coraz większego zainteresowania badaczy z obszaru nauk społecznych, ponieważ znacznie się różnią od tych, które przejawia poprzednie pokolenie. Związane to jest przede wszystkim z problemami, jakie coraz częściej sygnalizują osoby zarządzające współczesnymi organizacjami, które wskazują na negatywne cechy tzw. Igreków: lenistwo, niedojrzałość, nieodpowiedzialność czy brak szacunku dla pracy. Stereotypowo są postrzegani jako pokolenie, które ma wszystko, a któremu nic się nie chce. W dodatku co piąta osoba w tym wieku należy do grupy określanej jako NEET (od ang. no education, employment, training) - nie pracują, nie są wykształceni do wykonywania zawodu oraz nie edukują się w żaden inny sposób - nie uczestniczą w kursach ani szkoleniach. Nie podejmują pracy, bo nie mogą (ich zdaniem) znaleźć wystarczająco dobrej pracy, którą mogliby zaakceptować. Dla Igreków sama praca ma inną wartość niż dla pokolenia ich rodziców, to dla nich tylko część życia, dlatego niechętnie podejmują pracę, która wymagałaby poświęceń w życiu osobistym, i jeśli nie muszą, często odsuwają to w czasie.

I chociaż w Polsce to pokolenie niżu demograficznego, to w skali ogólnoświatowej jest to największe pokolenie, które stanowi blisko połowę siły roboczej. Generacja ta budzi wiele kontrowersji, przypisuje jej się brak lojalności, lenistwo, egoizm i arogancję - pytanie, czy słusznie.

\section{Pokolenie $Y$ a praca}

Głównym wyróżnikiem pokolenia, poza wiekiem, są dynamiczne przemiany historyczne, społeczne czy kulturowe charakterystyczne dla czasów, w których dana generacja się urodziła, wychowała bądź żyje. Poszczególne generacje mają specyficzne doświadczenia, które kształtują wartości przez nie dzielone, lub zachowania, np. różnią się od innych pokoleń stosunkiem 
do takich wartości, jak rodzina, praca, ojczyzna. Można obserwować u przedstawicieli określonych pokoleń cechy, które są reprezentowane przez wiele osób. I chociaż grupy te są, oczywiście, wewnętrznie zróżnicowane, to w literaturze możemy spotkać się z opisami głównych tendencji stanowiących znaki rozpoznawcze poszczególnych pokoleń.

Osoby należące do pokolenia Y to młodzi dorośli, choć najstarsi z nich mogą już mieć blisko czterdzieści lat. Dorastali w gospodarce wolnorynkowej, z rosnącym udziałem usług (co ukształtowało orientację konsumencką). W gospodarce coraz większego znaczenia nabierała wiedza, następował niezwykle gwałtowny rozwój technologii teleinformatycznych, które gruntownie zmieniły charakter współczesnej pracy, podobnie zresztą jak globalizacja (Chirkowska-Smolak, 2007). Jak wskazywała Sylwia Stachowska (2012), pokolenie Y miało praktycznie nieograniczone możliwości edukacji i rozwoju zawodowego, zna języki, wiele podróżuje. Miało do czynienia ze stosunkowo wysokim standardem życia i konsumpcji, dlatego, zdaniem tej autorki, Igreki są przyzwyczajone do natychmiastowej gratyfikacji. Są przy tym skupione na sobie, mają wysoką samoocenę i potrzebę samorealizacji. Osoby te są pewne siebie, przekonane o własnej wyjątkowości, mają wygórowane oczekiwania wobec życia i pracy oraz trudności z przyjmowaniem krytyki (Krahn i Galambos, 2014).

Często badacze podkreślają zjawisko odroczonego moratorium (Brzezińska, Kaczan, Piotrowski, Rękosiewicz, 2011) oraz rolę rodziców w życiu młodych ludzi (Wrzesień, 2007; Lipkin i Perrymore, 2009). Pokolenie ich rodziców (tzw. pokolenie X) przechodziło przez okres transformacji i musiało nauczyć się żyć w nowych realiach oraz dokonać przewartościowania ważnych aspektów swojego życia. Iksy odrabiały zaległości statusowe, próbowały zasypać przepaść, jaka dzieliła nasze społeczeństwo od Zachodu i, jak zauważają Michał Boni i Krystyna Szafraniec (2011), podnoszenie statusu materialnego stało się sensem ich życia, co pociągnęło za sobą brak równowagi praca-życie. Swoim dzieciom z pokolenia Y nie przekazywali jednak tych wartości, starali się, żeby ich dzieci nie popełniły takich błędów jak oni, stawiając pracę na pierwszym miejscu. Wychowywali swoje dzieci, zapewniając je, że mają nieograniczone możliwości i mogą być kimkolwiek zechcą (Chester, 2006; Wrzesień, Żurek i Przybył, 2005). Uczyli Igreków, że świat skoncentrowany jest wokół ich potrzeb, oraz wychowywali ich, chroniąc przed nieprzyjemnościami i porażkami (Baskin, 2011). Nadmierna ochrona, izolowanie od trudnych doświadczeń mogło wpłynąć na to, że ich dzieci z pokolenia Y nie potrafią ponosić odpowiedzialności za swoje czyny i zachowania, znosić frustracji ani radzić sobie z porażkami (Lipkin i Perrymore, 2009). 
Wszystko to mogło wpływać też na etykę pracy, odmienną od tej, która cechowała poprzednie pokolenia, mogło przyczynić się do tego, że Igreki nie umieją radzić sobie ze stresem, że przenoszą oczekiwania opieki na swojego przełożonego, oczekują zrozumienia przez przełożonego i wsparcia podobnego do tego, jakiego doświadczali przez całe życie od rodziców. Jednocześnie partnerskie traktowanie Igreków przez rodziców sprawiło, że pokolenie to nie uznaje autorytetu osób starszych od siebie. Uważają oni, że na szacunek należy sobie zasłużyć, a przełożonych traktują jak równych sobie pracowników, ale z szerszymi kompetencjami. Przedstawiciele tego pokolenia są wybredni i mają wysokie oczekiwania - praca nie może ich ograniczać, nie uznają sztywnych ram pracy, oczekują szybkiego awansu i docenienia ciężkiej pracy (Lipkin i Perrymore, 2009). Mają też problem z odpowiedzialnością za własne błędy i trudność z zaakceptowaniem informacji zwrotnej. Stad, jak się wydaje, dość ważny w kontekście lojalności wydaje się problem relacji pomiędzy pracownikami a przełożonymi.

Jak wskazują wyniki wieloletnich badań Deloitte, Igreki oczekują, że to pracodawcy powinni dopasować się do ich potrzeb. Z kolei oni nie muszą przestrzegać wszystkich zasad, ale tylko te, które mają sens, w przeciwnym wypadku będą tworzyć własne. Podobnie chcą wykonywać zadania, które są zgodne z ich wartościami i wymagające, w przeciwnym wypadku zmieniają pracodawcę. Igreki stosunkowo często zmieniają miejsce pracy, bo co około dwa lata (Deloitte, 2015). Nie myślą o pracy w danej organizacji w perspektywie długofalowej i są skłonni zmienić pracę, gdy zostanie im zaproponowana bardziej atrakcyjna oferta (Zgłobik, 2008). Dla pracodawców dużym wyzwaniem stały się te częste zmiany miejsca pracy przez młodych ludzi, w dodatku porównanie poziomu rotacji na rynkach pracy w Unii Europejskiej wskazuje na to, że to właśnie w Polsce jest największa liczba tzw. „jumpersów” (Instytut Badawczy Randstad, 2015).

Pokoleniu Y przypisuje się również brak lojalności oraz przywiązania do organizacji. Jego przedstawiciele mogli obserwować losy swoich lojalnych wobec organizacji rodziców, gotowych do pracy na każde wezwanie, których pełne zaangażowanie w pracę nie chroniło jednak przed jej utratą. Przywiązanie do organizacji przestało być adaptacyjnym zachowaniem, obecnie bardziej uzasadnione jest przywiązanie do zawodu i dbałość o własną karierę (Chirkowska-Smolak, Hauziński i Łaciak, 2011). Przy czym wyniki badań Łukasza Jurka (2014) pokazują, że ludzie chętnie wiązaliby się na dłużej z organizacją, gdyby widzieli, że organizacje są lojalne wobec nich, że są zaangażowane w swoją załogę i że zależy im na utrzymaniu pracowników. Młodzi z pokolenia Y czują się odpowiedzialni przede 
wszystkim za rozwój własnej kariery. Podejmując decyzje dotyczące pracy i zatrudnienia, biorą pod uwagę głównie swoje korzyści (Bednarska-Wnuk, 2014). Jak zauważa Alicja Smolbik-Jęczmień (2013a), Igreki są skoncentrowane na realizacji własnych potrzeb, a nie potrzeb organizacji, w której są zatrudnione, nie przywiązują się do jednego miejsca pracy, sprawdzają różne możliwości, jakie oferuje im rynek pracy, by móc realizować swoje pragnienia i hobby poza pracą, dlatego tak ważna jest dla nich możliwość zachowania równowagi pomiędzy pracą a życiem osobistym. Z kolei dla przedstawicieli pokolenia X praca sama w sobie może nadawać sens w życiu i stwarzać możliwość samorealizacji. Przełożonym z pokolenia X trudno zrozumieć, że młodzi pracownicy nie identyfikują się z organizacją, w której pracują, i bez skrupułów przechodzą do innej organizacji tylko dlatego, że zaoferowano im nieco wyższe wynagrodzenie. Gdy zaś są niezadowoleni z warunków pracy, uważają, że nie są traktowani sprawiedliwie.

Stąd powszechne przekonanie, że przedstawiciele pokolenia Y są nielojalni, gdyż lojalność jest często utożsamiana z przywiązaniem do organizacji, swego rodzaju wiernością jednemu pracodawcy. Jak twierdzi na przykład Jurek (2014), lojalny pracownik to taki, który docenia stabilność pracy i nie szuka alternatywnych miejsc pracy, stąd częstotliwość zmian miejsc pracy może być uznana za wskaźnik lojalności. Autor ten sugeruje, że młodzi pracownicy nie tyle wykazują się brakiem lojalności, co większą mobilnością wynikającą z wieku. Niewątpliwie, na początku kariery zawodowej łatwiej jest zmienić pracę, a nawet zawód, nauczyć się nowych obowiązków bądź zmienić miejsce zamieszkania w poszukiwaniu lepszej pracy. A do zmiany pracy młodzi ludzie są często zmuszeni, bo zbyt mało zarabiają, nie mają szansy na awans lub sąźle traktowani. Jednak z wiekiem ta mobilność maleje; możemy też obserwować efekt utopionych kosztów w odniesieniu do pracy zawodowej (Godin, 2007).

$\mathrm{Z}$ tego powodu autorzy często podkreślają, że ważnym predyktorem lojalności pracowników jest satysfakcja z pracy (Lam, Baum i Pine, 2001; Bednarska-Wnuk, 2014). Satysfakcja z pracy odnosi się do pozytywnej postawy, pozytywnego stosunku i odczuć ludzi do pracy, którą wykonują. Wyniki badań często pokazują, że poziom satysfakcji z pracy rośnie wraz z wiekiem i stażem pracy. Wydaje się to dość oczywiste, ponieważ na początku kariery zawodowej, gdy pracownik nie ma jeszcze wystarczających kompetencji i doświadczenia do zaoferowania pracodawcy, trudno o satysfakcjonującą pracę - zadania są niedopasowane: albo zbyt trudne, albo zbyt łatwe, ich wykonywanie nie zapewnia ani gratyfikacji zewnętrznej, ani wewnętrznej. Najmniej zadowoleni z pracy są młodzi pracownicy wkraczający na rynek pracy. Ta zależność potwierdza się u pracowników 
fizycznych i umysłowych, u kobiet i u mężczyzn. Satysfakcja z pracy jest zdecydowanie wyższa u pracowników dojrzałych (Schultz i Schultz, 2008).

Wskazuje się również na sprawiedliwość organizacyjną jako czynnik warunkujący lojalność pracowników. Wygórowane oczekiwania wobec pracy i brak wcześniejszych doświadczeń związanych z pracą sprawiają, że rozczarowani warunkami młodzi ludzie są przekonani, iż organizacja traktuje ich nieuczciwie. Sprawiedliwość organizacyjna, rozumiana jako ogólna uczciwość spostrzegana w środowisku pracy, wpływa na wykazywanie przez pracowników odpowiednich reakcji, a także na ich nastawienie oraz zaufanie do przełożonych i firmy (Macko, 2009). Brak sprawiedliwości prowadzi z kolei do działań na niekorzyść organizacji, powoduje odczucie gniewu czy nawet agresji oraz zmniejsza lojalność pracowników (Rizvi, 2016). Z kolei sprawiedliwość zapewnia pracownikom poczucie bezpieczeństwa, redukuje obawy, że zostaną przez organizację wykorzystani i porzuceni, i sprzyja przywiązaniu do organizacji oraz lojalności.

\section{Lojalność wobec organizacji}

Model kariery zakładający pracę w jednej organizacji przez całe życie stracił swoją aktualność, a wyznacznikiem lojalności nie jest już bezwarunkowe, długotrwałe pozostawanie w jednym miejscu pracy - cechą współczesnych organizacji jest przecież zmienność, mobilność i elastyczność (Chirkowska-Smolak, 2007). Czy lojalność w dzisiejszych czasach ma jeszcze jakiś sens? Czy, jak się zastanawiała Anna Lewicka-Strzałecka (2014), stanowi trwałą wartość czy anachroniczną cnotę?

Należy uznać, że pojęcie lojalności względem organizacji wymaga rewizji i redefinicji, choć w literaturze przedmiotu trudno doszukać się prac, w których próbowano by się uporać z problemem niezależności tego konstruktu (Coughlan, 2005), utożsamianego najczęściej z wiernością wobec organizacji, mierzoną długością pozostawania w jednym miejscu pracy. Bob Voyles (1999) wskazuje na to, że z lojalnością mamy do czynienia wtedy, gdy pracownik pozostaje przez dłuższy czas w organizacji, gdy jest oddany realizacji celów organizacyjnych i gdy rozwija się w organizacji.

Lojalność jest najczęściej utożsamiana z innymi konstruktami (Wnuk i Chirkowska-Smolak, 2017) znanymi na gruncie psychologii pracy i organizacji, takimi jak przywiązanie organizacyjne (Mowday, Porter i Steers, 1982; Bloemer i Odekerken-Schroder, 2006; Lipka, Winnicka-Wejs i Acedański, 2012) czy zamiar opuszczenia lub pozostania w organizacji (Solomon, 1992; 
Russ i McNeilly, 1994; Jurek, 2014; Otto i Mamatoglu, 2015), a według innych autorów wskaźnikiem lojalności jest zaangażowanie w pracę (Świątek-Barylska, 2013).

W klasycznym już ujęciu Jill W. Graham (1991) lojalność jest rozumiana jako identyfikacja z organizacją, wierność jej liderom i organizacji jako całości oraz wykraczanie przez pracowników poza własne interesy, a nawet interesy własnego zespołu pracowniczego czy działu i dbanie o interesy całej organizacji. Zachowania charakterystyczne dla lojalnych pracowników to np. obrona organizacji przed zagrożeniami, dbanie o dobrą reputację firmy, współpraca z innymi, by służyć interesom całości. Kluczowe w tym wszystkim jest, jak się zdaje, troszczenie się przez pracowników o pozytywny wizerunek organizacji jako przejaw dbałości o jej dobro, np. pozytywne wyrażanie się na temat organizacji (Varona, 2002) czy polecanie pracy w firmie swoim bliskim i znajomym (Antoncic i Antoncic, 2011). Juan M. Elegido (2013) sugerował, że lojalność stanowi zamierzone zobowiązanie do jak najlepszego dbania o interes organizacji nawet wtedy, kiedy działania te mogą wymagać poświecenia niektórych aspektów własnego interesu. Należy dodać, że działania pracowników w tym zakresie mogą wykraczać poza powinności wynikające z prawa czy moralności.

Lojalność wobec organizacji można wyjaśniać na gruncie koncepcji wymiany pracownik-organizacja. Wymiana między obiema stronami dokonuje się na podstawie wzajemnych oczekiwań, które znajdują odzwierciedlenie w kontrakcie psychologicznym (Ratajczak, 2007). Organizacja daje pracownikowi możliwość realizacji potrzeb społeczno-emocjonalnych, z kolei, jak sugerował Robert Eisenberger ze współpracownikami, pracownik czuje się zobowiązany do odwdzięczenia się - dla uniknięcia dysonansu pomiędzy tym, jak się jest traktowanym przez organizację i jak się jej za to rewanżuje, dla zachowania pozytywnego obrazu siebie, uniknięcia stygmatyzacji jako osoby, która nie wyrównuje rachunków, oraz utrzymania pozytywnego traktowania z jej strony (Eisenberger, Armeli, Rexwinkel, Lynch i Rhoades, 2001). Dbanie zaś o pozytywny wizerunek organizacji jest łatwo dostępnym i prostym sposobem odpłacenia się organizacji, niewymagającym szczególnego zaangażowania i poświęceń.

Jak zauważają Marcin Wnuk i Teresa Chirkowska-Smolak (2017), poza dbaniem o pozytywny wizerunek organizacji drugim aspektem składającym się na lojalność organizacyjną jest skłonność do poświęceń i wyrzeczeń na rzecz organizacji - lojalny pracownik przejawia skłonność do rezygnacji z własnego interesu dla dobra organizacji. Jest to cnota będąca konsekwencją procesu socjalizacji oraz internalizacji norm i wartości, która ulega utrwalaniu w trakcie rozwoju. Podobnie twierdzi Teresa Ronginska (2012), według której lojalność ma wyraźny wydźwięk moralno-etyczny, ponieważ w lojalnym 
zachowaniu ujawniają się wartości i normy człowieka nabyte w procesie socjalizacji. W tym przypadku możemy mówić o niezależności od reguły wzajemności, gdyż jest to dyspozycja względnie stała w czasie i w znacznej mierze niezależna od okoliczności. Oznacza to, że lojalny pracownik będzie potrafił poświęcić swój wolny czas na rzecz organizacji, kiedy okoliczności będą tego wymagały, czy nawet czasowo zrezygnować ze swoich ambicji bądź aspiracji dla dobra organizacji niezależnie od tego, gdzie będzie pracował.

Powstaje zatem pytanie, czy lojalność zależy od obiektu lojalności, czy może jest wartością samą w sobie. Można przecież zauważyć, że dyspozycja do przedkładania interesu oraz dobra organizacji nad swój własny interes naraża pracownika na bycie oszukanym i wykorzystanym, a w niektórych przypadkach może prowadzić nawet do sprzeniewierzenia się własnym wartościom i przekonaniom (Lewicka-Strzałecka, 2014). Na względną ocenę lojalności wskazywała na przykład Maria Ossowska (1970), zauważając, że może ona zależeć od przedmiotu lojalności, bo w niektórych sytuacjach (np. gdy władza jest obca lub narzucona) lojalność może oznaczać oportunizm lub serwilizm. Z kolei Piotr Sztompka wskazywał, że lojalność stanowi wartość autoteliczną - „powinność nienaruszania zaufania, jakim obdarzają nas inni, i wywiązywania się z podjętych zobowiązań” (Sztompka, 2007, s. 36).

Wydaje się jednak, że lojalność łączy w sobie oba te aspekty, tj. względnie trwałe postawy, na które mogą mieć wpływ czynniki kontekstu. W niniejszej pracy traktuję lojalność wobec organizacji jako postawę moralną składającą się z dwóch elementów: (1) skłonności do poświęceń oraz wyrzeczeń na rzecz organizacji jako cnoty będącej wynikiem socjalizacji, doświadczeń życiowych oraz internalizacji norm i wartości oraz (2) dbania o pozytywny wizerunek organizacji jako pozytywnej reakcji uzależnionej od postrzegania przez pracownika efektywności wymiany społecznej.

\section{Metoda}

Celem niniejszych analiz jest sprawdzenie zależności pomiędzy poziomem lojalności organizacyjnej a satysfakcją z pracy i poczuciem sprawiedliwości organizacyjnej. Spodziewałam się pozytywnej zależności pomiędzy lojalnością a satysfakcją (hipoteza 1) i sprawiedliwością (hipoteza 2), ponieważ jednak traktuję lojalność jako postawę moralną, która zależy nie tylko od wymiany pomiędzy pracownikiem a organizacją ale jest bardziej trwałą dyspozycją (cnotą), będącą wynikiem socjalizacji i internalizacji norm, oczekiwałam, że zależności pomiędzy tymi zmiennymi, choć istotne, będą na poziomie umiarkowanym. 
Głównym problemem badawczym było sprawdzenie, czy przedstawiciele dwóch pokoleń, określanych jako X iY, różnią się poziomem lojalności wobec organizacji. Ze względu jednak na to, że pokolenie Y obejmuje dość szeroką grupę wiekową (duża rozpiętość, od 20. do blisko 40. roku życia), wyróżniłam dwie podgrupy: młodszych badanych do 30. roku życia (biorąc pod uwagę wyniki badań m.in. Brzezińskiej, które wskazują na wydłużony okres dorastania do pełnej dorosłości) oraz badanych z pokolenia Y plus, w wieku od 30. do 38. roku życia. Spodziewałam się, że osoby z pokolenia Y będą mniej lojalne wobec organizacji w porównaniu z osobami z pokolenia ich rodziców (X), a także że młodsi przedstawiciele pokolenia Y będą mniej lojalni od „Igreków plus”.

\subsection{Procedura badań}

Badanie przeprowadzono w trzech etapach w okresie od kwietnia 2017 do maja $2018 \mathrm{r} .{ }^{1} \mathrm{~W}$ badaniu 1 analizowano zależność pomiędzy lojalnością wobec organizacji a satysfakcją z pracy, w badaniu 2 zależność pomiędzy lojalnością a sprawiedliwością organizacyjną, zaś w badaniu 3 pomiędzy lojalnością a zachowaniami obywatelskimi i satysfakcją z pracy. W badaniu brały udział osoby dorosłe, które przepracowały minimum pół roku. Były one zatrudnione głównie w usługach, handlu oraz w przedsiębiorstwach produkcyjnych.

\subsection{Charakterystyka osób badanych}

W badaniu 1 wzięło udział 336 osób, z czego 59,8\% stanowiły kobiety, a 40,2\% mężczyźni. Były to osoby w wieku od 20 do 68 lat. Średnia wieku wynosiła 31 lat ( $\mathrm{M}=30,99, \mathrm{SD}=9,32)$, średni staż pracy wynosił 9,5 roku (SD = 9,06). Najwięcej było młodszych przedstawicieli pokolenia Y $(57 \%)$, starsi przedstawiciele pokolenia Y stanowili 28,2\% badanych, a przedstawiciele pokolenia $X-14,7 \%$.

W badaniu 2 wzięło udział 213 osób, z czego 66\% stanowiły kobiety, a 34\% mężczyźni. Były to osoby w wieku od 20 do 60 lat. Średnia wieku wynosiła 34,5 roku ( $M=34,55, S D=7,71)$, średni staż pracy wynosił 13 lat $(S D=7,86)$. Młodszych przedstawicieli pokolenia Y było 34,7\%), starsi przedstawiciele pokolenia $Y$ stanowili 31,5\% badanych, a przedstawiciele pokolenia $\mathrm{X}-33,8 \%$.

W badaniu 3 wzięło udział 118 osób, z czego 80,5\% stanowiły kobiety, a 19,5\% mężczyźni. Były to osoby w wieku od 19 do 56 lat. Średnia wieku

${ }^{1}$ Badania 2 i 3 zostały przeprowadzone w ramach seminarium magisterskiego, we współpracy z Mariuszem Tomaszewskim i Ignacym Stebelskim. 
wynosiła 29 lat ( $\mathrm{M}=$ 28,79, SD = 7,71). Najwięcej było młodszych przedstawicieli pokolenia Y (71,2\%), starsi przedstawiciele pokolenia Y stanowili 16,9\% badanych, a przedstawiciele pokolenia $\mathrm{X}-11,9 \%$.

\subsection{Zastosowane narzędzia}

Do pomiaru lojalności wobec organizacji wykorzystano Skalę Lojalności wobec Organizacji autorstwa Chirkowskiej-Smolak i Wnuka (2017). Narzędzie składa się z 12 pozycji dotyczących dbania o pozytywny wizerunek organizacji (Godnie reprezentuję mojq̨ organizację/firmę) oraz skłonności do poświęceń i wyrzeczeń na rzecz organizacji (Jestem gotowy do poniesienia pewnych wyrzeczeń na rzecz mojej organizacji/firmy). Badani odpowiadali na skali od 1 (zdecydowanie się nie zgadzam) do 5 (zdecydowanie się zgadzam). Narzędzie uzyskało dobre współczynniki rzetelności ( $\alpha$ Cronbacha wyniosła 0,87 ).

Satysfakcja z pracy była mierzona za pomocą kwestionariusza opracowanego przez Paula Spectora w 1985 r. - Job Satisfaction Survey (JSS) w polskiej adaptacji Chirkowskiej-Smolak (2012). Zawiera on 36 pozycji dotyczących różnych aspektów pracy składających się na 9 skal: płace, awans, przełożeni, benefity, wynagradzanie oparte na wykonaniu, procedury, współpracownicy, właściwości pracy i komunikacja $(\alpha=0,91)$. Badani ustosunkowują się do stwierdzeń na 6-punktowej skali od 1 (zupełnie się nie zgadzam) do 6 (w pełni się zgadzam). Dla polskiej wersji językowej $\alpha$ Cronbacha $=0,85$.

Do pomiaru sprawiedliwości organizacyjnej wykorzystano Kwestionariusz Sprawiedliwości Organizacyjnej autorstwa Macieja Macki. Kwestionariusz ten składa się z 32 stwierdzeń odnoszących się do sytuacji zachodzących w firmie i warunków zatrudnienia. Badani odpowiadali na czterostopniowej skali, gdzie 1 oznaczało „zdecydowanie się nie zgadzam”, a 4 - ,zdecydowanie się zgadzam”. Rzetelność testu jest wysoka, $\alpha$ Cronbacha wyniosła 0,94.

\section{Wyniki}

\subsection{Opis statystyczny zmiennych}

\section{Lojalność wobec organizacji}

Poziom lojalności wobec organizacji był zbliżony w poszczególnych grupach wiekowych w każdym z trzech badań (tabela 1). Rozkład zmiennej był zgodny z rozkładem normalnym tylko w badaniu trzecim. 
Tabela 1. Statystyki opisowe (średnie i odchylenia standardowe oraz parametry rozkładu) dla lojalności wobec organizacji w poszczególnych grupach wiekowych

\begin{tabular}{|l|c|c|c|}
\hline \multirow{2}{*}{$\begin{array}{c}\text { Wiek } \\
\text { badanych }\end{array}$} & \multicolumn{3}{|c|}{ Lojalność wobec organizacji (M i SD) w poszczególnych badaniach } \\
\cline { 2 - 4 } & $\begin{array}{c}\text { Badanie } 1 \\
(\mathrm{~N}=336)\end{array}$ & $\begin{array}{c}\text { Badanie } 2 \\
(\mathrm{~N}=213)\end{array}$ & $\begin{array}{c}\text { Badanie 3 } \\
(\mathrm{N}=118)\end{array}$ \\
\hline Poniżej 30 lat & $3,37(0,40)$ & $2,93(0,38)$ & $2,97(0,57)$ \\
\hline 30-38 lat & $3,55(0,42)$ & $3,04(0,37)$ & $3,2(0,47)$ \\
\hline Powyżej 38 lat & $3,54(0,33)$ & $3,13(0,33)$ & $3,36(0,45)$ \\
\hline Test K-S & $0,083(p<0,0001)$ & $0,080(p=0,002)$ & $0,067(p=0,20)$ \\
\hline
\end{tabular}

Źródło: opracowanie własne.

\section{Satysfakcja z pracy}

Satysfakcja z pracy mierzona była w badaniach 1 i 3 . Do niniejszych analiz wykorzystane zostaną dane dotyczące satysfakcji z pracy ogółem oraz na podskali Relacje z przełożonymi. Statystyki opisowe dla satysfakcji z pracy przedstawia tabela 2 . W przypadku relacji z przełożonymi można zauważyć większe rozproszenie wyników wokół średniej oraz to, że badani we wszystkich grupach wiekowych w obu badaniach uzyskiwali wyższe wyniki na podskali Relacji z przełożonymi w porównaniu ze średnim wynikiem dla satysfakcji z pracy ogółem.

Tabela 2. Statystyki opisowe (średnie i odchylenia standardowe) dla satysfakcji z pracy w badaniach 1 i 3

\begin{tabular}{|c|c|c|c|c|}
\hline Badanie & $\begin{array}{c}\text { Grupa } \\
\text { wiekowa }\end{array}$ & $\begin{array}{c}\text { Satysfakcja } \\
\text { z pracy ogółem } \\
\text { M (SD) }\end{array}$ & $\begin{array}{c}\text { Satysfakcja z relacji } \\
\text { z przełożonym } \\
\text { M (SD) }\end{array}$ & $\begin{array}{c}\text { Sprawiedliwość } \\
\text { organizacyjna }\end{array}$ \\
\hline \multirow{3}{*}{ Badanie 1} & poniżej 30 lat & $3,75(0,82)$ & $4,27(1,26)$ & \\
\hline & 30-38 lat & $3,72(0,99)$ & $4,37(1,33)$ & \\
\hline & \begin{tabular}{|l} 
powyżej \\
38 lat \\
\end{tabular} & $3,55(0,92)$ & $4,01(1,48)$ & \\
\hline \multirow{3}{*}{ Badanie 3} & poniżej 30 lat & $3,58(0,71)$ & $4,17(1,18)$ & \\
\hline & 30-38 lat & $3,49(0,72)$ & $4,18(0,92)$ & \\
\hline & \begin{tabular}{|l} 
powyżej \\
38 lat \\
\end{tabular} & $3,66(0,69)$ & $4,45(1,16)$ & \\
\hline \multirow{3}{*}{ Badanie 2} & poniżej 30 lat & & & $2,65(0,60)$ \\
\hline & 30-38 lat & & & $2,50(0,54)$ \\
\hline & $\begin{array}{l}\text { powyżej } \\
38 \text { lat }\end{array}$ & & & $2,51(0,56)$ \\
\hline
\end{tabular}

Źródło: opracowanie własne. 
Rozkład satysfakcji dla wyniku ogólnego był zgodny z rozkładem normalnym tylko w badaniu 1 (odpowiednio dla badania $1 p=0,07$ i dla badania 3 $p<0,0001$ ), natomiast w przypadku podskali Relacji z przełożonym w obu badaniach odbiegał od rozkładu normalnego ( $p<0,0001)$.

\section{Sprawiedliwość organizacyjna}

Zmienna ta była wykorzystywana tylko w badaniu 2. Średni poziom poczucia sprawiedliwości organizacyjnej (ogółem) wyniósł $M=2,56, S D=0,57$ ); podobny poziom sprawiedliwości organizacyjnej był postrzegany przez pracowników z poszczególnych kategorii wiekowych. Rozkład zmiennej był zgodny z rozkładem normalnym $(p=0,20)$.

\subsection{Wyniki testowania hipotez}

Lojalność a satysfakcja z pracy i poczucie sprawiedliwości organizacyjnej Tabela 3 przedstawia wyniki analizy zależności pomiędzy lojalnością organizacyjną a satysfakcją z pracy ogółem i satysfakcją z relacji z przełożonym w badaniach 1 i 3. Wszystkie związki okazały się istotne na co najmniej umiarkowanym poziomie.

Tabela 3. Współczynniki korelacji (rho-Spearmana) pomiędzy lojalnością organizacyjną a satysfakcją z pracy w badaniach 1 i 3

\begin{tabular}{|c|c|c|c|c|}
\hline \multicolumn{2}{|c|}{ Lojalność w badaniu } & $\begin{array}{c}\text { Satysfakcja } \\
\text { ogółem }\end{array}$ & $\begin{array}{c}\text { Satysfakcja z relacji } \\
\text { z przełożonym }\end{array}$ & $\begin{array}{c}\text { Sprawiedliwość } \\
\text { organizacyjna }\end{array}$ \\
\hline \multirow{3}{*}{ Lojalność } & w badaniu 1 & $0,464^{* *}$ & $0,414^{* *}$ & \\
\cline { 2 - 5 } & w badaniu 3 & $0,56^{* *}$ & $0,46^{* *}$ & $0,37 * *$ \\
\cline { 2 - 5 } & w badaniu 2 & & & Źródło: opracowanie własne. \\
** korelacja istotna na poziomie 0,01 \\
źn
\end{tabular}

Przyjrzenie się tym wynikom w podziale na poszczególne kategorie wiekowe pokazało, że siła związku pomiędzy lojalnością a satysfakcją z pracy była podobna - w badaniu 1 rho wynosiło odpowiednio 0,496, 0,479 i 0,47, a w badaniu 3 odpowiednio 0,55, 0,55 i 0,66. Istotna różnica współczynników korelacji dotyczyła tylko najstarszych badanych (tzw. Iksów) z badania 3, u których związek lojalności z satysfakcją był istotnie silniejszy niż w przypadku tej zależności u pracowników z pokolenia Y (z Fishera wyniosło 1,32, $p=0,009$ ).

Związek pomiędzy lojalnością wobec organizacji a sprawiedliwością organizacyjną (ogółem) okazał się istotny na poziomie umiarkowanym, 
korelacja była dodatnia. Najsilniejszy związek występował u najmłodszych badanych $(0,487)$, następnie u „Igreków plus” $(0,44)$, słaby związek pomiędzy lojalnością a sprawiedliwością występował u pracowników z pokolenia X $(0,24)$. Wartość $z$ Fishera przy porównaniu współczynników korelacji u badanych pracowników z pokolenia Y i pokolenia X wyniosła z = 3,07, $p=0,0011$.

Różnice w lojalności wobec organizacji pomiędzy przedstawicielami pokoleń Xi $Y$ Wielkość różnic dotyczących lojalności organizacyjnej pomiędzy poszczególnymi grupami wiekowymi przedstawia tabela 4.

Tabela 4. Wartości różnic pomiędzy średnimi lojalności organizacyjnej dla poszczególnych grup wiekowych

\begin{tabular}{|l|c|c|c|c|}
\hline \multicolumn{1}{|c|}{ Badanie } & H Kruskala-Wallisa & $p$ & $\eta^{2}$ & $\begin{array}{c}\text { Wielkość efektu } \\
d \text { Cohena** }\end{array}$ \\
\hline Badanie 1 & 15,24 & $<0,0001$ & 0,04 & 0,41 \\
\hline Badanie 2 & 12,55 & 0,002 & 0,05 & 0,46 \\
\hline Badanie 3 & 9,57 & 0,008 & 0,056 & 0,53 \\
\hline
\end{tabular}

Źródło: opracowanie własne.

Porównania parami (U Manna-Whitneya) wykazały istotne różnice pomiędzy najmłodszymi badanymi a zarówno przedstawicielami pokolenia $\mathrm{X}$ $(p=0,021)$, jak i starszymi przedstawicielami pokolenia $\mathrm{Y}(p=0,002)$.

Porównania w badaniu 2 wykazały istotną różnicę pomiędzy najmłodszymi badanymi z pokolenia $\mathrm{Y}$ a badanymi z pokolenia $\mathrm{X}(p=0,002)$; brak było różnic istotnych statystycznie pomiędzy osobami pomiędzy 30. a 40. rokiem życia a osobami młodszymi (z pokolenia Y), a także osobami starszymi (X). Podobnie w badaniu 3, istotnie różnili się najmłodsi badani z pokolenia Y od przedstawicieli pokolenia $X(p=0,035)$.

Siłę efektu oszacowano z wykorzystaniem kalkulatora internetowego (udostępnianego przez instytucję Psychometrica Online). Uzyskane wartości $d$ Cohena wskazują na umiarkowane wielkości efektu uzyskane we wszystkich trzech badaniach.

\section{Dyskusja wyników i wnioski}

Wyniki przeprowadzonych badań potwierdziły w większości postawione hipotezy. Lojalność wobec organizacji jest związana z satysfakcją z pracy ogółem (w różnych jej obszarach) i satysfakcją z relacji z przełożonym, jednak nie jest to silny związek. Poziom zadowolenia z pracy był umiarkowany 
w obu badaniach, w których wykorzystywano tę zmienną, zbliżony we wszystkich grupach wiekowych i nieco silniejszy (w porównaniu do satysfakcji ogółem) w przypadku relacji z przełożonym (był jednak również na poziomie umiarkowanym).

Nie można zatem mówić, że młodzi pracownicy (z pokolenia Y) są lojalni wtedy, gdy praca przynosi im satysfakcję - umiarkowanie dodatnie korelacje występują u pracowników we wszystkich grupach wiekowych, a w badaniu 3 związek ten jest nawet silniejszy (istotny statystycznie) u pracowników starszych.

Z kolei w badaniu 2 wyraźnie było widać, że u starszych pracowników (pokolenie $\mathrm{X}$ ) postrzegana sprawiedliwość organizacyjna ma już nieco mniejsze znaczenie dla lojalności wobec organizacji. Trzeba przy tym zaznaczyć, że sprawiedliwość organizacyjna była postrzegana bardzo podobnie przez pracowników ze wszystkich wyróżnionych kategorii wiekowych, a tylko zależność lojalności od sprawiedliwości była słabsza u Iksów.

Trudno mówić, by lojalność była wartością autoteliczną, cnotą wpojoną w dzieciństwie i kultywowaną w dorosłym życiu bez względu na okoliczności, w jakich jednostka się znajduje. Lojalność organizacyjna związana jest w umiarkowany sposób z satysfakcją z pracy i poczuciem sprawiedliwości organizacyjnej. Jest to o tyle ważne, że zarządzający mogą dbać o zapewnienie odpowiednich warunków pracy, zamiast mało konstruktywnie narzekać na brak lojalności określonej grupy pracowników, którzy zaczynają tworzyć trzon załogi w wielu organizacjach. Umiarkowane zależności mogą jednak sugerować, że oprócz czynników organizacyjnych lojalność mogą wyznaczać zmienne indywidualne.

Jednak do twierdzenia, że młodzi pracownicy nie są tak lojalni jak pracownicy z pokolenia ich rodziców, pracodawcy mają podstawy. We wszystkich trzech badaniach poziom lojalności rósł z wiekiem. Wyniki wszystkich trzech prezentowanych badań pokazują, że u młodych pracowników (znajdujących się w okresie wyłaniającej się dorosłości) poziom lojalności faktycznie jest najniższy. Podobnie potwierdziły się często formułowane opinie dotyczące pracowników z pokolenia X - poziom lojalności w tej grupie wiekowej był najwyższy.

Interesujące wyniki dotyczyły natomiast starszych przedstawicieli pokolenia Y - nie zawsze różnili się oni lojalnością wobec organizacji (w istotny statystycznie sposób) od pracowników z pokolenia X. Sugeruje to, że trudno mówić o pokoleniu Y jako jednorodnej grupie, rozpiętość wieku w obrębie tego pokolenia to dwadzieścia lat, a postawy wobec pracy, jak widać na przykładzie lojalności organizacyjnej, mogą być zróżnicowane - czasami bardziej zbliżone 
do postaw przejawianych przez poprzednią generację niż przez osoby zaliczane do tego samego pokolenia. Sytuacja życiowa i zawodowa przedstawicieli tej generacji może ograniczać mobilność, rodzicom jest coraz trudniej, nawet psychologicznie, rozpinać parasol nad swoimi dorosłymi dziećmi, wreszcie należy uznać, że po okresie odraczania dorosłości dojrzeli do podejmowania zadań, jakie przed nimi stoją. Część z nich dojrzała również do lojalności.

\section{Literatura}

Ali, A. (1993). Decision making style, individualism, and attitudes toward risk of Arab executives. International Studies of Management and Organization, 23 (3), 53-73.

Antoncic, J. A., Antoncic, B. (2011). Employee loyalty and its impact on firm growth. International Journal of Management \& Information Systems, 15 (1), 81-87.

Baskin, S. (2011). The gift of failure, https://www.psychologytoday.com/blog/smores-andmore/201112/the-gift-failure, dostęp: 13.07.2018.

Bednarska-Wnuk, I. (2014). The effect of changes on management of Generation Y employees: A study case of Poland. Mediterranean Journal of Social Sciences, 5, 141-146, http://www.mcser.org/journal/index.php/mjss/article/view/4187, dostęp: 13.07.2018.

Bloemer, J., Odekerken-Schroder, G. (2006). The role of employee relationship proneness in creating employee loyalty. International Journal of Bank Marketing, 24 (4), 252-264.

Boni, M., Szafraniec, K. (2011). Młodzi 2011. Warszawa: Kancelaria Prezesa Rady Ministrów.

Brzezińska, A. I., Kaczan, R., Piotrowski, K., Rękosiewicz, M. (2011). Odroczona dorosłość: fakt czy artefakt? Nauka, 4, 67-107.

Chester, E. (2006). Młodzi w pracy. Jak zadbać o pracowników z pokolenia Y. Gliwice: Helion.

Chirkowska-Smolak, T. (2007). Przemiany pracy w dobie globalizacji. W: J. Włodarek (red.), Studia z socjologii pracy, organizacji i rynku (ss. 13-28). Poznań: Wyższa Szkoła Komunikacji i Zarządzania.

Chirkowska-Smolak, T. (2012). Psychologiczny model zaangażowania w pracę. Poznań: Wydawnictwo Naukowe UAM.

Chirkowska-Smolak, T., Hauziński, A., Łaciak, M. (2011). Drogi kariery. Jak wspomagać rozwój zawodowy dzieci i młodzieży. Warszawa: Wydawnictwo Naukowe Scholar.

Coughlan, R. (2005). Employee loyalty as adherence to shared moral values. Journal of Managerial Issues, 1, 43-57.

Eisenberger, R., Armeli, S., Rexwinkel, B., Lynch, P. D., Rhoades, L. (2001). Reciprocation of perceived organizational support. Journal of Applied Psychology, 86, 42-51.

Elegido, J. (2013). Does it make sense to be a loyal employee? Journal of Business Ethics, 3, (116), 495-511.

Godin, S. (2007). Dołek, czyli kiedy brnqć, a kiedy rezygnować. Gliwice: OnePress.

Graham, J. W. (1991). Leadership, moral development, and citizenship behavior. Business Ethics Quarterly, 5 (1), 43-54.

Instytut Badawczy Randstad (2015). Monitor Rynku Pracy. Raport z 20. edycji badania 14 lipca 2015 r., http:// www.outsourcingportal.eu/pl/userfiles/image/raporty/2015/7/14/ Monitor_Rynku_Pracy_20_edycja_prezentacja_14_07_2015, dostęp: 13.07.2018. 
Instytut Badawczy Randstad (2017). Monitor Rynku Pracy. Raport z 28. edycji badania 11 lipca 2017 r., https://www.professionals.randstad.pl/o-randstad/o-randstad/monitorrynku-pracy-11072017s/ http://ec.europa.eu/eurostat, dostęp: 13.07.2018.

Jurek, Ł. (2014). (Nie)lojalność pracowników z pokolenia Y. Nauki o Zarzq̨dzaniu, 3 (20), 44-54.

Krahn, H., Galambos, N. (2014). Work values and beliefs of 'Generation X' and 'Generation Y'. Journal of Youth Studies, 17 (1), 92-112.

Lam, T., Baum, T., Pine, R. (2001). Study of managerial job satisfaction in Hong Kong's chinese restaurants. International Journal of Contemporary Hospitality, 13 (1), 35-42.

Lewicka-Strzałecka, A. (2014). Lojalność pracowników - trwała wartość czy anachroniczna cnota. Człowiek i Społeczeństwo, 38, 147-164.

Lipka, A., Winnicka-Wejs, A., Acedański, J. (2012). Lojalność pracownicza. Od diagnozy typów lojalności pracowników po zarzq̨dzanie relacjami z pracownikami. Warszawa: Difin.

Lipkin, N., Perrymore, A. (2009). Y in the workplace. Managing the „Me First” Generation. New York: Career Press.

Macko, M. (2009). Poczucie sprawiedliwości organizacyjnej a zachowania pracowników. Poznań: Wydawnictwo Naukowe Wydziału Nauk Społecznych UAM.

Mowday, R., Porter, L., Steers, R. (1982). Employee-Organization Linkages: The Psychology of Commitment, Absenteeism, and Turnover. New York: Academic Press.

Ossowska, M. (1970). Normy moralne. Warszawa: PWN.

Otto, K., Mamatoglu, N. (2015). Why does interactional justice promote organizational loyalty, job performance, and prevent mental impairment? The role of social support and social stressors. Journal of Psychology, 149, 193-218.

Deloitte (2015). Pierwsze kroki na rynku pracy Liderzy przyszłości, Raport badawczy Deloitte, 2015, https://www2.deloitte.com/content/dam/Deloitte/pl/Documents/Reports/ pl_Raport-PierwszeKroki-2015.pdf, dostęp: 13.07.2018.

Ratajczak, Z. (2007). Psychologia pracy i organizacji. Warszawa: Wydawnictwo Naukowe PWN.

Rizvi, S. (2016). The effect of psychological capital on employees' voice and loyalty responses to organizational injustice: A two dimensional approach. Journal of Managerial Sciences, 10, 151-175.

Ronginska, T. (2012). Lojalność pracownika czynnikiem sukcesu organizacji. Problemy Profesjologii, 1, 23-32.

Russ, F. A., McNeilly, K. M. (1994). Critical sales events and sales force attitudes. Marketing Letters, 5, 235-244.

Schultz, D., Schultz, S. (2008). Psychologia a wyzwania dzisiejszej pracy, przeł. G. Kranas. Warszawa: Wydawnictwo Naukowe PWN.

Smolbik-Jęczmień, A. (2013a). Rozwój kariery zawodowej wśród przedstawicieli pokolenia X i Y. Nowe wyzwania. Modern Management Review, 18, 191-202.

Smolbik-Jęczmień, A. (2013b). Podejście do pracy i kariery zawodowej wśród przedstawicieli generacji X i Y - podobieństwa i różnice. Nauki o zarzq̨dzaniu, 1 (14), 89-97.

Solomon, C. (1992). The loyalty factor, Personnel Journal, 23, 52-62.

Stachowska, S. (2012). Oczekiwania przedstawicieli pokolenia Y wobec pracy i pracodawcy. Zarzq̨dzanie Zasobami Ludzkimi, 2, 33-56. 
Sztompka, P. (2007). Zaufanie. Kraków: Znak.

Świątek-Barylska, I. (2013). Lojalność pracowników współczesnych organizacji: istota i elementy składowe. Łódź: Wydawnictwo Uniwersytetu Łódzkiego.

Varona, F. (2002). Conceptualization and management of communication satisfaction and organizational commitment in three Guatemalan organizations. Online American Communication Journal, 5 (3), 114-136.

Voyles, B. (1999). Are satisfied employees loyal employees? Potentials, 32 (9), 69-70.

Wnuk, M., Chirkowska-Smolak, T. (2017), Właściwości psychometryczne Skali Lojalność wobec Organizacji, referat przygotowany na 36. Kongres Polskiego Towarzystwa Psychologicznego „Psychologia dla zdrowia osoby i społeczeństwa”, Gdańsk, 21-24 września $2017 \mathrm{r}$.

Wrzesień, W. (2007). Czy pokoleniowość nam się nie przydarzy? Nauka, 3, 131-151.

Wrzesień, W., Żurek, A., Przybył, I. (2005). Rodzice i ich dzieci w tańcu pokoleń. Poznań: Wydawnictwo Naukowe UAM.

Zgłobik R. (2008), Pokolenie Y, https://www.eurostudent.pl/pokolenie-y, dostęp: 13.07.2018. 